\title{
Studi Upah dan Beban Biaya Pekerja Konstruksi di Indonesia (Studi Kasus: Pekerja Konstruksi Gedung di Pulau Jawa)
}

\author{
Srie Heruyani Stevia Lukmanasari \\ Jurusan Teknik Sipil, Fakultas Teknik Sipil dan Perencanaan, Institut Teknologi Nasional \\ Jl. PH. H. Mustofa No.23, Cikutra, Cibeunying Kidul, Kota Bandung \\ E-mail: stevialukmanasari@gmail.com \\ Biemo W. Soemardi \\ Jurusan Teknik Sipil, Fakultas Teknik Sipil dan Lingkungan, Institut Teknologi Bandung \\ Jl. Ganeca No. 10 Bandung \\ E-mail: b_soemardi@si.itb.ac.id
}

\begin{abstract}
Labor wages have a large portion (approximately 30\%) of construction contract value. Therefore, company should pay attention to labor wages. Unfortunately, existing data about construction labor wages in Indonesian are only showed as daily wages (for labor) and monthly wages (for employee/permanent staff), while there's no information about their labor burden. Therefore, objectives of this study are to identify the component and structure of construction labor burden and wages in Indonesia and also to identify all factors related. Research method used int this study are empirical and inductive methods. After all data has been collected from field survey, description of the construction labor burden and wages model was compiled into its components. Moreover, comparison analysis used to identify factors related to construction labor burden and wages. Results of data processing and analysis shows that: 1) Construction labor burden in Indonesia for both employee/permanent staff and labor commonly consist of direct and indirect payment, and conditional and lumpsum payment, but there are different distributions between each kind of labor. 2) Construction labor burden and wages in Indonesia commonly depend on company profile, project profile, and labor profile.
\end{abstract}

Keywords: Construction workers, Construction worker's wages, Constrction labor burden.

\begin{abstract}
Abstrak
Upah pekerja merupakan komponen yang cukup besar porsinya (sekitar 30\%) di dalam nilai konstruksi. Oleh karena itu, biaya ini perlu mendapat perhatian yang serius dari perusahaan. Sayangnya dari data yang ada, informasi terkait upah pekerja konstruksi di Indonesia hanya berupa upah harian (untuk pekerja lepas) dan upah bulanan (untuk pekerja tetap), sementara informasi mengenai beban biaya pekerja tidak tersedia. Oleh karena itu penelitian ini bertujuan untuk mengidentifikasi komponen-komponen beban biaya pekerja dan proporsinya terhadap keseluruhan biaya upah pekerja konstruksi di Indonesia; dan juga untuk Mengidentifikasi faktor-faktor yang berhubungan dengan upah dan beban biaya pekerja konstruksi di Indonesia. Metode penelitian yang digunakan untuk mencapai tujuan tersebut adalah metode empiris dan induktif. Data yang telah terkumpul dari survei lapangan selanjutnya diolah dan dianalisis menggunakan statistik deskriptif dan analisis perbandingan. Metode statistik deskriptif digunakan untuk memodelkan beban biaya pekerja menjadi komponen-komponennya beserta proporsi masing-masing, sedangkan metode analisis perbandingan digunakan untuk menganalisis variabel-variabel yang berpengaruh terhadap upah dan beban biaya pekerja. Dari hasil pengolahan data tersebut, disusun kesimpulan dengan metode induktif sebagai berikut: 1) Secara umum, beban biaya pekerja baik untuk pekerja tetap maupun pekerja lepas dikelompokkan menjadi biaya yang dibayarkan secara langsung dan tidak langsung, dan yang bersifat kondisional serta lumpsum per proyek, namun distribusi masing-masing komponen biayanya berbeda antara pekerja tetap dan pekerja lepas; 2) Secara umum tingkat upah dan beban biaya pekerja konstruksi di Indonesia tergantung pada profil perusahaan, profil proyek, dan profil pekerja.
\end{abstract}

Kata-kata Kunci: Pekerja konstruksi, Upah pekerja konstruksi, Beban biaya pekerja konstruksi. 


\section{Pendahuluan}

Upah secara singkat dapat dikatakan sebagai kompensasi yang diterima oleh pekerja dari perusahaan atas hasil kerjanya. Dari hasil survei Badan Pusat Statistik, dinamika besaran upah pekerja tetap dan harian konstruksi dalam beberapa tahun terakhir ada pada Tabel 1 .

Dari Tabel 1 terlihat bahwa kompensasi pekerja konstruksi di Indonesia saat ini hanya diwujudkan dalam bentuk upah harian (untuk pekerja lepas) dan upah bulanan/gaji (untuk pekerja tetap). Padahal masih terdapat biaya-biaya lain di luar upah/gaji tersebut (yang didefinisikan sebagai beban biaya pekerja) yang mana informasi mengenai hal tersebut belum tersedia di Indonesia.

Hal yang berbeda dijumpai di negara-negara maju, seperti Amerika dan Eropa. Negara-negara di kawasan tersebut telah mampu memodelkan beban biaya pekerja konstruksi menjadi komponenkomponen penyusunnya, beserta besaran/proporsi dan ketentuan pemberiannya.

Jadi, dapat disimpulkan bahwa sistem pengupahan pekerja konstruksi di Indonesia memiliki perbedaan yang cukup signifikan dengan sistem pengupahan di negara-negara maju. Perbedaan ini terletak pada keterbatasan informasi mengenai beban biaya pekerja konstruksi di Indonesia di mana hal tersebut tidak berlaku di luar negeri. Keterbatasan ini berakibat pada sulitnya mengestimasi secara akurat beban biaya pekerja yang harus ditanggung oleh kontraktor. Lebih lanjut, akan berakibat pula pada ketiadaan informasi mengenai kontribusi biaya upah terhadap nilai tambah produk konstruksi.

\section{Kajian literatur}

\section{Perusahaan kontraktor}

Peraturan LPJKN No. 10 Tahun 2013 tentang Registrasi Usaha Jasa Pelaksana Konstruksi menyebut perusahaan kontraktor dengan istilah usaha jasa pelaksana konstruksi dan mendefinisikannya sebagai jenis usaha jasa konstruksi yang menyediakan layanan jasa pelaksanaan pekerjaan konstruksi, yang dibedakan menurut bentuk usaha, klasifikasi, dan kualifikasi usaha jasa pelaksana konstruksi.

Masih menurut peraturan yang sama, pasal 10 ayat (1) menyebutkan bahwa penggolongan kualifikasi usaha jasa pelaksana konstruksi didasarkan pada kriteria tingkat/kedalaman kompetensi dan potensi kemampuan usaha, serta kemampuan melakukan pelaksana pekerjaan. Untuk penetapan atas tingkat/kedalaman kompetensi dan potensi kemampuan usaha jasa pelaksana konstruksi meliputi kriteria risiko dan/atau kriteria penggunaan dan/atau kriteria besaran biasa. Perusahaan kontraktor terbagi menjadi 4 kualifikasi, yaitu orang perseorangan $(\mathrm{P})$, usaha kecil (K1, K2, K3), usaha menengah (M1, M2) dan usaha besar (M1, M2).

\section{Pekerja dalam industri konstruksi}

Definisi pekerja menurut UU No. 13 Tahun 2003 pasal 1 tentang Ketenagakerjaan adalah setiap orang yang bekerja dengan menerima upah atau imbalan dalam bentuk lain.

Pada industri konstruksi, pekerja merupakan komponen vital perusahaan. Pekerja merupakan penggerak utama kegiatan-kegiatan konstruksi. Sumber daya lain harus diolah oleh pekerja untuk bisa menjadi produk konstruksi yang diinginkan. Sebagai kompensasinya, perusahaan membayar upah yang layak dan sebanding dengan kinerja pekerja tersebut. Dan karena pekerja adalah manusia yang bersifat dinamis dan merupakan komponen yang mahal dalam industri konstruksi, maka perusahaan perlu memberi perhatian lebih kepada pekerjanya.

Dalam menjalankan aktivitasnya, perusahaan menggunakan suatu bentuk strategi sumber daya manusia (human resources strategy), di mana untuk memenuhi kebutuhan sumber daya manusia perusahaan, perusahaan menggunakan dua jenis pekerja, yaitu pekerja tetap (yang berasal dari dalam perusahaan) dan outsourcee (pekerja yang berasal dari luar perusahaan/pekerja kontrak). Pekerja tetap adalah pekerja yang bekerja pada perusahaan dengan waktu kerja penuh (full-time) serta memiliki suatu jenjang karir dalam struktur organisasi perusahaan. Sedangkan outsourcee adalah yang bekerja pada perusahaan untuk melakukan pekerjaan tertentu dengan menerima upah, yang didasarkan atas kesepakatan dalam hubungan kerja untuk waktu tertentu dan atau selesainya pekerjaan tertentu.

Upah dan beban biaya pekerja

Upah merupakan hak pekerja/buruh yang diterima dan dinyatakan dalam bentuk uang sebagai imbalan dari pengusaha atau pemberi kerja kepada pekerja/buruh yang ditetapkan dan dibayarkan menurut suatu perjanjian kerja, kesepakatan atau peraturan perundang-undangan, termasuk tunjangan dari pekerja/buruh dan keluarganya atas suatu pekerjaan dan/atau jasa yang telah atau akan dilakukan (UU No. 13 Tahun 2003 tentang Ketenagakerjaan pasal 1).

Dari kutipan di atas dapat dilihat bahwa perusahaan harus menanggung tunjangan/biayabiaya lain yang berhubungan dengan pekerja di 
luar upah pokoknya. Namun seperti telah di sampaikan di awal, informasi mengenai struktur upah pekerja konstruksi di Indonesia saat ini masih hanya berupa gaji bulanan (untuk pekerja tetap) dan upah harian (untuk pekerja lepas).

Negara-negara maju seperti di Amerika dan Eropa telah berhasil mengidentifikasi struktur upah pekerja konstruksinya. Sebagai contoh seperti yang disampaikan oleh Huston (2004), komponen beban biaya pekerja konstruksi di Amerika terdiri dari Federal Insurance Contributions Act (FICA), Federal Unemployment Tax Act (FUTA), General Liability Insuranse (GLI), holidays, medical/health insurance, State Unemployment Tax Act (SUTA), sick days, vacations, well days, dan Worker's Compensation Insurance (WCI). Jika semua komponen tersebut diakumulasikan, maka tingkat beban biaya pekerja pada umumnya berkisar antara $12-15 \%$ untuk pekerja tetap (permanent staff) dan 20-35\% untuk pekerja lepas (free-labor).

Sedangkan di Kanada, beban biaya pekerja pada umumnya berkisar antara 10-20\% untuk pekerja tetap dan lepas, yang terdiri dari (tapi tidak terbatas pada) additional health coverage that is not included in the provincial plan (such as medical, prescription, vision and dental plans), Group Disability (STD/LTD), Employee Assistance Plans (EAP), Group Term Life \& Accidental Death \& Dismemberment, health and dependent care, retirement benefit plans (in addition to Canada Pension Plan (CPP)), long term care insurance plans, legal assistance plans, transportation benefits, serta possibly other miscellaneous employee discounts: wellness programs, discounted shopping, hotels and resorts.

Besarnya beban biaya pekerja tentunya berbeda antara satu dengan yang lain. Perbedaan ini berdasarkan pada umur mereka, tanggungan atau kepemilikan di perusahaan (Hedley, 2007). Selain itu, jenis pekerjaan pun mempengaruhi tingkat beban biaya pekerja (Rabinaw, 2006).

\section{Peraturan terkait Ketenagakerjaan di Indonesia}

Secara umum, peraturan ketenagakerjaan di Indonesia diatur dalam UU No. 13 Tahun 2003 tentang Ketenagakerjaan. Terdapat dua poin yang berkaitan dengan penelitian ini, yaitu mengenai kompetensi kerja dan hak-hak pekerja.

\section{Kompetensi kerja}

Definisi kompetensi kerja menurut UU No. 13 Tahun 2003 adalah kemampuan kerja setiap individu yang mencakup aspek pengetahuan, keterampilan, dan sikap kerja yang sesuai dengan standar yang ditetapkan. Untuk menentukan tingkat kompetensi kerja, diperlukan suatu acuan dalam pembinaan, persiapan SDM yang berkualitas, kompeten yang diakui oleh seluruh pemangku kepentingan, dan berlaku secara nasional di wilayah NKRI. Acuan ini yang selanjutnya dikenal sebagai Standar Kompetensi Kerja Nasional Indonesia (SKKNI). Menurut Peraturan Menteri Tenaga Kerja dan Transmigrasi Republik Indonesia No. 5 Tahun 2012, yang dimaksud dengan SKKNI adalah rumusan kemampuan kerja yang mencakup aspek pengetahuan, keterampilan dan/atau keahlian serta sikap kerja yang relevan dengan pelaksanaan tugas dan syarat jabatan yang ditetapkan sesuai dengan ketentuan peraturan perundang-undangan.

SKKNI diterapkan di bidang pelatihan kerja dan sertifikasi kompetensi. Pelatihan kerja adalah keseluruhan kegiatan untuk memberi, memperoleh, meningkatkan, serta mengembangkan kompetensi kerja, produktivitas, disiplin, sikap, dan etos kerja pada tingkat keterampilan dan keahlian tertentu sesuai dengan jenjang dan kualifikasi jabatan atau pekerjaan. Pelatihan kerja ini diselenggarakan oleh lembaga pelatihan kerja pemerintah yang bekerja sama dengan pihak yang berkepentingan.

Setelah menyelesaikan pelatihan kerja, pekerja berhak mendapatkan sertifikat pelatihan dan atau sertifikat kompetensi kerja. Sertifikat pelatihan kerja diberikan oleh lembaga yang mengadakan pelatihan. Sedangkan sertifikat kompetensi kerja diberikan oleh LPJK setelah pekerja lulus uji kompetensi.

Dalam industri konstruksi, dikenal dua macam sertifikasi terhadap pekerja, yaitu Sertifikat Keahlian Kerja (SKA) dan Sertifikat Keterampilan Kerja (SKTK). SKA adalah sertifikat yang diterbitkan LPJK dan diberikan kepada tenaga kerja ahli konstruksi yang telah memenuhi persyaratan berdasarkan disiplin keilmuan, kefungsian dan atau keahlian tertentu. Sedangkan SKTK adalah sertifikat yang diberikan kepada tenaga kerja terampil yang telah memenuhi persyaratan berdasarkan disiplin keilmuan dan/atau keterampilan tertentu.

\section{Hak-hak Pekerja}

Sebagai unsur sumberdaya penting dalam konstruksi, pekerja konstruksi mempunyai hak-hak yang dilindungi oleh undang-undang, termasuk hak terhadap upah dan beban biaya pekerja lainnya. Di Indonesia, hak-hak pekerja tersebut yang tertuang dalam UU No. 13 Tahun 2003 tentang Ketenagakerjaan yang mengatur tentang ketenagakerjaan di Indonesia secara umum, 
Srie Heruyani Stevia Lukmanasari, Biemo W. Soemardi

Studi Upah dan Beban Biaya Pekerja Konstruksi di Indonesia (Studi Kasus: Pekerja Konstruksi Gedung di Pulau Jawa)

Tabel 1. Sebaran upah pekerja konstruksi tahun 2008-2012

\begin{tabular}{|c|c|c|c|c|c|c|c|c|}
\hline No. & Rincian & Satuan & 2008 & 2009 & 2010 & 2011 & 2012 & Rata-rata \\
\hline A. & \multicolumn{8}{|c|}{ Pekerja tetap } \\
\hline 1 & $\begin{array}{l}\text { Balas jasa } \\
\text { pekerja tetap } \\
\text { konstruksi }\end{array}$ & $10^{6} \mathrm{Rp}$ & 9.998 .430 & 12.057 .703 & 14.354 .550 & 16.467 .786 & 18.665 .146 & 14.308 .723 \\
\hline 2 & $\begin{array}{l}\text { Pertumbuhan } \\
\text { balas jasa (y-o-y) }\end{array}$ & $\%$ & 21,03 & 20,6 & 19,05 & 14,72 & 13,34 & 17,75 \\
\hline 3 & $\begin{array}{l}\text { Rata-rata balas } \\
\text { jasa }\end{array}$ & $\mathrm{Rp}$ & 1.069 .997 & 1.206 .341 & 1.337 .566 & 1.457 .785 & 1.739 .861 & 1.362 .310 \\
\hline 4 & $\begin{array}{l}\text { Pertumbuhan } \\
\text { rata-rata balas } \\
\text { jasa (y-o-y) }\end{array}$ & $\%$ & 12,67 & 12,74 & 10,88 & 8,99 & 19,35 & 12,93 \\
\hline B. & \multicolumn{8}{|c|}{ Pekerja lepas (pekerja harian) } \\
\hline 1 & $\begin{array}{l}\text { Upah pekerja } \\
\text { harian konstruksi }\end{array}$ & $10^{6} \mathrm{Rp}$ & 39.850 .568 & 48.061 .820 & 57.231 .676 & 65.601 .041 & 74.351 .799 & 57.019 .381 \\
\hline 2 & $\begin{array}{l}\text { Pertumbuhan } \\
\text { upah (y-o-y) }\end{array}$ & $\%$ & 21,31 & 20,61 & 19,08 & 14,62 & 13,34 & 17,79 \\
\hline 3 & Rata-rata upah & $\mathrm{Rp}$ & 52.205 & 54.938 & 57.837 & 62.108 & 69.828 & $59.383,2$ \\
\hline 4 & $\begin{array}{l}\text { Pertumbuhan } \\
\text { rata-rata upah } \\
(y-0-y)\end{array}$ & $\%$ & 6,7 & 5,24 & 5,28 & 7,38 & 12,43 & 7,41 \\
\hline
\end{tabular}

termasuk hak-hak pekerja. Hak-hak pekerja tersebut adalah:

1. Pelatihan kerja (pasal 9).

2. Jam kerja (pasal 77).

3. Istirahat kerja (pasal 79 ayat (2) poin a).

4. Hari libur (pasal 79-85).

5. Pengaturan cuti dalam Perjanjian Kerja/PK, Peraturan Perusahaan/PP, atau Peraturan Kerja Bersama/PKB (pasal 79 ayat (3))

6. Kebijakan pengupahan (pasal 88 ayat (3)).

7. Jamsostek (pasal 99 ayat (1)). Pengaturan lebih lanjut tentang penyelenggaraan Jamsostek tercantum dalam PP No. 84 Tahun 2013 tentang Perubahan Kesembilan atas PP No. 14 Tahun 1993 tentang Penyelenggaraan Program Jamsostek.

8. Upah minimum (pasal 94).

\section{Rancangan Penelitian}

Dari uraian di atas dapat disimpulkan bahwa informasi yang jelas dan rinci mengenai sistem pembebanan biaya pekerja konstruksi sangat penting artinya dalam rangka mengetahui hubungan antara komponen-komponen biaya upah terhadap nilai tambah produk konstruksi. Guna mencapai hal itu, perlu disusun suatu rancangan penelitian yang bertujuan untuk:

1. Mengidentifikasi komponen-komponen beban biaya pekerja dan proporsinya terhadap keseluruhan biaya upah pekerja konstruksi di Indonesia;
2. Mengidentifikasi seluruh faktor-faktor yang berhubungan dengan upah dan beban biaya pekerja konstruksi di Indonesia.

Mengingat akan luasnya cakupan dan sebaran pekerja konstruksi di Indonesia, maka pada tahap penelitian ini dibatasi untuk hal-hal sebagai berikut:

1. Sampel utama pada penelitian ini adalah pekerja (baik tetap maupun lepas) pada proyek gedung yang dilaksanakan oleh perusahaan kontraktor gred besar.

2. Lokasi studi difokuskan di kota-kota besar di Pulau Jawa karena konsentrasi pekerjaan dan pekerja konstruksi gedung ada di Pulau Jawa.

Guna mencapai maksud dan tujuan penelitian seperti yang telah disampaikan sebelumnya, maka dibutuhkan suatu rancangan metode penelitian yang akan digunakan. Metode tersebut adalah gabungan antara metode empiris dengan metode induktif. Metode empiris digunakan dengan cara survei langsung ke lapangan guna memperoleh informasi objektif berupa upah pekerja. Data-data yang telah terkumpul selanjutnya diolah dan dianalisis menggunakan statistik deskriptif dan analisis perbandingan. Metode statistik deskriptif digunakan untuk memodelkan beban biaya pekerja menjadi komponen-komponennya beserta persentase masing-masing. Selain itu, dianalisis pula faktor-faktor yang berhubungan dengan tingkat upah dan beban biaya pekerja dengan metode analisis perbandingan (Independent- 
Samples $T$ test, One Way Anova, dan KruskalWallis). Variabel dalam penelitian ini dikelompokkan menjadi dua, yaitu:

1. Variabel dependen, terdiri dari:

- Gaji/upah pekerja konstruksi.

- Beban biaya pekerja konstruksi, berupa fasilitas-fasilitas yang diperoleh pekerja dari perusahaan.

2. Variabel independen, terdiri dari:

- Profil perusahaan kontraktor (jenis, kualifikasi, dan pengalaman perusahaan).

- Profil proyek konstruksi (kota, keberadaan kantor pusat atau cabang, nilai kontrak, dan durasi proyek).

- Profil pekerja konstruksi, baik pekerja tetap maupun lepas (status kepegawaian, jenis kelamin dan usia, pendidikan, pengalaman kerja, posisi/jabatan, sertifikasi, dan status pernikahan pekerja).

Selanjutnya, disusun dua tipe kuesioner berdasarkan variable-variabel tersebut, yaitu:

\section{Kuesioner Tipe A}

Kuesioner ini digunakan untuk mengetahui apakah variabel profil perusahaan dan proyek berhubungan dengan variabel upah dan beban biaya pekerja kontruksi. Targetnya adalah pemberi upah dan beban biaya pekerja konstruksi, yaitu proyek.

\section{Kuesioner Tipe B}

Kuesioner ini digunakan untuk mengetahui apakah variabel profil pekerja berhubungan dengan variabel upah dan beban biaya pekerja konstruksi. Targetnya adalah penerima upah dan beban biaya pekerja konstruksi, yaitu pekerja pada proyek konstruksi gedung.

\section{Data dan Analisis Data}

\section{Perolehan data}

Berdasarkan rancangan penelitian, responden pada penelitian ini adalah proyek konstruksi gedung yang dikerjakan oleh perusahaan kontraktor gred besar beserta pekerja tetap dan pekerja lepasnya. Namun terdapat perkembangan pada saat proses pengumpulan data, di mana responden yang diperoleh tidak hanya berasal dari kontraktor gred besar saja namun juga dari gred menengah. Responden ini tersebar di berbagai kota, jenis perusahaan, kualifikasi perusahaan, durasi proyek, nilai kontrak proyek.

Dari hasil pengumpulan data, terlihat bahwa responden yang diperoleh lebih banyak berasal dari perusahaan kontraktor swasta nasional. Hal ini disebabkan karena jumlah kontraktor BUMN di Indonesia jauh lebih sedikit (hanya 7 perusahaan) jika dibandingkan dengan jumlah kontraktor swasta nasional. Selain itu, terlihat pula bahwa mayoritas proyek besar di Indonesia membutuhkan waktu pelaksanaan multi years. Untuk responden pekerja, hierarki umumnya seperti yang tercantum pada Gambar 1. Dapat dilihat bahwa secara umum, pekerja konstruksi terbagi menjadi 2 jenis, yaitu pekerja tetap dan pekerja lepas. Dalam penelitian ini, pekerja tetap dibagi lagi menjadi pekerja pada posisi kantor dan pada posisi lapangan.

Tabel 2. Responden proyek berdasarkan lokasi

\begin{tabular}{clcc}
\hline No & Kota & Jumlah proyek & Persentase \\
\hline 1 & Bandung & 6 & $22 \%$ \\
2 & Jakarta & 5 & $19 \%$ \\
3 & Semarang & 2 & $7 \%$ \\
4 & Surabaya & 5 & $19 \%$ \\
5 & Yogyakarta & 9 & $33 \%$ \\
\hline & Total & 27 & $100 \%$ \\
\hline
\end{tabular}

Tabel 3. Responden proyek berdasarkan jenis perusahaan

\begin{tabular}{cccc}
\hline No & $\begin{array}{c}\text { Jenis } \\
\text { perusahaan }\end{array}$ & Jumlah proyek Persentase \\
\hline 1 & BUMN & 12 & $44 \%$ \\
2 & Swasta nasional & 15 & $56 \%$ \\
\hline & Total & 27 & $100 \%$ \\
\hline
\end{tabular}

Tabel 4. Responden proyek berdasarkan kualifikasi perusahaan

\begin{tabular}{clcc}
\hline No & $\begin{array}{c}\text { Kualifikasi } \\
\text { perusahaan }\end{array}$ & Jumlah proyek & Persentase \\
\hline 1 & M1 & 4 & $15 \%$ \\
2 & M2 & 4 & $15 \%$ \\
3 & B1 & 5 & $19 \%$ \\
4 & B2 & 14 & $52 \%$ \\
\hline \multicolumn{2}{c}{ Total } & 27 & $100 \%$ \\
\hline
\end{tabular}

Tabel 5. Responden proyek berdasarkan durasi

\begin{tabular}{cccc}
\hline No & Durasi & Jumlah proyek & Persentase \\
\hline 1 & $<1$ tahun & 4 & $15 \%$ \\
2 & $1-2$ tahun & 20 & $74 \%$ \\
3 & $2-3$ tahun & 3 & $11 \%$ \\
\hline \multicolumn{2}{c}{ Total } & 27 & $100 \%$ \\
\hline
\end{tabular}

Tabel 6. Responden proyek berdasarkan nilai kontrak

\begin{tabular}{cccc}
\hline No & Nilai kontrak Jumlah proyek & Persentase \\
\hline 1 & $1-25 \mathrm{M}$ & 2 & $7 \%$ \\
2 & $26-30 \mathrm{M}$ & 6 & $22 \%$ \\
3 & $51-75 \mathrm{M}$ & 3 & $11 \%$ \\
4 & $76-100 \mathrm{M}$ & 3 & $11 \%$ \\
5 & $101-125 \mathrm{M}$ & 2 & $7 \%$ \\
6 & $>125 \mathrm{M}$ & 11 & $41 \%$ \\
\hline \multicolumn{2}{c}{ Total } & 27 & $100 \%$ \\
\hline
\end{tabular}


Srie Heruyani Stevia Lukmanasari, Biemo W. Soemardi

Studi Upah dan Beban Biaya Pekerja Konstruksi di Indonesia (Studi Kasus: Pekerja Konstruksi Gedung di Pulau Jawa)

Tabel 7. Responden pekerja berdasarkan jenisnya

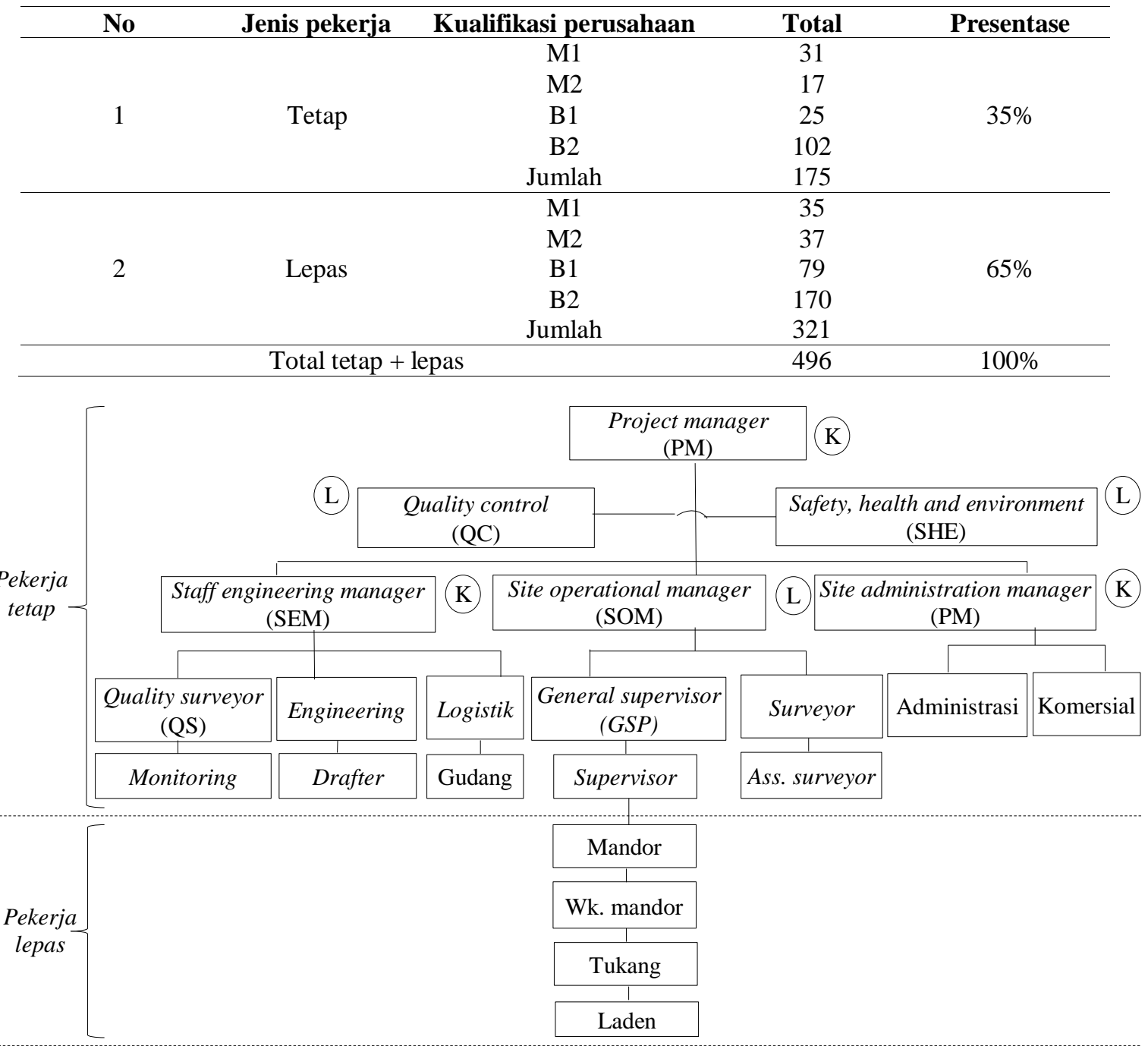

Gambar 1. Hierarki umum pekerja konstruksi

Sehingga perolehan responden pekerja berdasarkan jenisnya dapat dilihat pada Tabel 7.

Tabel 8. Responden pekerja tetap pada posisi kantor

\begin{tabular}{lcrrrr}
\hline \multirow{2}{*}{ Jabatan } & \multicolumn{4}{c}{ Kualifikasi perusahaan } & \multirow{2}{*}{ Total } \\
\cline { 2 - 5 } & M1 & M2 & B1 & B2 & \\
\hline PM & 2 & & & 3 & 5 \\
SEM & & & & 1 & 1 \\
SAM & & & 1 & 3 & 4 \\
QS & 2 & 1 & 7 & 8 & 18 \\
Engineer & 6 & 2 & 7 & 27 & 42 \\
Logistik & 2 & 1 & 1 & 8 & 12 \\
Admin & 3 & 2 & & 5 & 10 \\
Komersial & 1 & & & 2 & 3 \\
Drafter & 6 & 5 & 2 & 15 & 28 \\
Gudang & & & 1 & 2 & 3 \\
\hline Total & 22 & 11 & 19 & 74 & 126 \\
\hline
\end{tabular}

Dari Tabel 7 di atas dapat dilihat bahwa persentase pekerja lepas lebih besar dibandingkan persentase pekerja tetap. Hal ini disebabkan karena proyek konstruksi lebih banyak menggunakan pekerja lepas daripada pekerja tetap guna meminimalisasi biaya overhead. Sedangkan perolehan responden pekerja tetap baik pada posisi kantor maupun posisi lapangan, dapat dilihat pada Tabel 8 dan Tabel 9.

Tabel 9. Responden pekerja tetap pada posisi lapangan

\begin{tabular}{|c|c|c|c|c|c|}
\hline \multirow{2}{*}{ Jabatan } & \multicolumn{4}{|c|}{ Kualifikasi perusahaan } & \multirow[b]{2}{*}{ Total } \\
\hline & M1 & M2 & B1 & B2 & \\
\hline$\overline{\mathrm{QC}}$ & 1 & & & 4 & 5 \\
\hline SHE & & & 1 & 4 & 5 \\
\hline SOM & 1 & 1 & 1 & 2 & 5 \\
\hline GSP & 1 & 1 & & 5 & 7 \\
\hline Surveyor & 1 & & 1 & 22 & 4 \\
\hline SP & 5 & 4 & 2 & 10 & 21 \\
\hline Ass. Surveyor & & & 1 & 1 & 2 \\
\hline Total & 9 & 6 & 6 & 28 & 49 \\
\hline
\end{tabular}

Perolehan responden pekerja lepasnya adalah sebagai berikut: 
Tabel 10. Responden pekerja lepas

\begin{tabular}{|c|c|c|c|c|c|c|c|c|c|}
\hline \multirow{2}{*}{\begin{tabular}{|l} 
Kel. Pekerja \\
Perusahaan \\
\end{tabular}} & \multicolumn{2}{|c|}{ M1 } & \multicolumn{2}{|c|}{ M2 } & \multicolumn{2}{|c|}{ B1 } & \multicolumn{2}{|c|}{ B2 } & \multirow{2}{*}{ Total } \\
\hline & $\mathbf{T}$ & $\mathbf{L}$ & $\mathbf{T}$ & $\mathbf{L}$ & $\mathbf{T}$ & $\mathbf{L}$ & $\mathbf{T}$ & $\mathbf{L}$ & \\
\hline \multicolumn{10}{|l|}{ Arsitektur } \\
\hline Pasang bata/hebel & 10 & 4 & 3 & 1 & 8 & 1 & 19 & 10 & 56 \\
\hline Plester + aci & 1 & 1 & 3 & & 8 & & 5 & 3 & 21 \\
\hline Keramik & & & 3 & & 4 & & 2 & & 9 \\
\hline Plafon & 3 & 2 & & & 1 & & 3 & & 9 \\
\hline Cat & & & & & 3 & & 7 & 3 & 13 \\
\hline Landscape & & & & & & & 1 & 2 & 3 \\
\hline Alumunium + kaca & & & 1 & & 1 & & 2 & 1 & 5 \\
\hline Drainase & & & & & & & & 1 & 1 \\
\hline Façade & & & & & & & 2 & 2 & 4 \\
\hline Waterproof & & & 1 & & & & 1 & & 2 \\
\hline Furniture/interior & & & & & 1 & 1 & 1 & & 3 \\
\hline Railing tangga & & & & & & & 1 & & 1 \\
\hline \multicolumn{10}{|l|}{ Sipil } \\
\hline Gali tanah & & & & & & & 1 & & 1 \\
\hline Besi & 1 & 1 & 5 & 3 & 6 & 2 & 20 & 12 & 50 \\
\hline Cor & 1 & 2 & 1 & 1 & 4 & 2 & 8 & 9 & 28 \\
\hline Bekisting & 1 & 1 & 1 & 1 & 3 & 1 & 4 & 4 & 16 \\
\hline Precast & & & & & 1 & & 4 & 2 & 7 \\
\hline Kayu & & & 3 & 2 & 7 & & & & 12 \\
\hline Pancang & & & & & & & 2 & 2 & 4 \\
\hline \multicolumn{10}{|l|}{ Mep } \\
\hline Las & 1 & 1 & & 1 & 2 & & 4 & 4 & 13 \\
\hline Plumbing & & & & & 1 & 2 & 1 & & 4 \\
\hline Arus lemah & 1 & & & & & & & & 1 \\
\hline Teknisi listrik & 2 & 2 & & & 2 & & 2 & 1 & 9 \\
\hline Total & 21 & 14 & 21 & 9 & 52 & 9 & 90 & 56 & 272 \\
\hline Mandor & & & \multicolumn{2}{|c|}{4} & \multicolumn{2}{|c|}{9} & \multicolumn{2}{|c|}{9} & 22 \\
\hline Wakil mandor & & & \multicolumn{2}{|c|}{3} & \multicolumn{2}{|c|}{4} & \multicolumn{2}{|c|}{5} & 12 \\
\hline Grand total & \multicolumn{2}{|c|}{35} & \multicolumn{2}{|c|}{37} & \multicolumn{2}{|c|}{74} & \multicolumn{2}{|c|}{160} & 306 \\
\hline
\end{tabular}

Keterangan:

$\mathrm{T}=$ tukang; $\mathrm{L}=$ laden

\section{Analisis data}

\section{Asumsi perhitungan}

Sesuai dengan kajian literatur, beban biaya pekerja merupakan komponen biaya lain di luar upah/gaji yang harus ditanggung oleh perusahaan. Sehingga untuk selanjutnya, perhitungan upah dan beban biaya pekerja dilakukan secara terpisah.

2. Perhitungan upah dan beban biaya pekerja konstruksi

Perhitungan proporsi masing-masing komponen beban biaya pekerja terhadap keseluruhan biaya upah akan disajikan pada Tabel 12, Tabel 13, dan Tabel 14. Satu hal yang perlu diperhatikan adalah komponen dan tingkat beban biaya pekerja lepas (baik tukang, laden, mandor, maupun wakil mandor) adalah sama, yaitu hanya terdiri dari APD saja. Hal yang berbeda ditemui pada PM.

Meskipun komponen beban biaya pekerjanya sama dengan pekerja tetap lainnya, namun besarannya cukup berbeda. Seperti yang telah disebutkan pada Tabel 11 di atas bahwa ada pula beban biaya pekerja yang bersifat kondisional (misalnya uang transport, uang pulsa, premi asuransi kesehatan, bonus akhir tahun, dan bonus akhir proyek untuk pekerja tetap serta THR untuk tukang) dan yang dibayarkan lumpsum per proyek misalnya:

- mess pekerja tetap

- bedeng pekerja lepas

- $\quad$ iuran BPJS Ketenagakerjaan pekerja lepas 
Srie Heruyani Stevia Lukmanasari, Biemo W. Soemardi

Studi Upah dan Beban Biaya Pekerja Konstruksi di Indonesia (Studi Kasus: Pekerja Konstruksi Gedung di Pulau Jawa)

Tabel 11. Asumsi perhitungan upah dan beban biaya pekerja

\begin{tabular}{|c|c|c|c|}
\hline \multirow{2}{*}{ No. } & \multirow{2}{*}{ Komponen biaya } & \multicolumn{2}{|l|}{ Asumsi } \\
\hline & & Pekerja tetap & Pekerja lepas \\
\hline \multicolumn{4}{|c|}{ Upah } \\
\hline 1 & Upah/gaji & Gaji bulanan & Upah bulanan=upah harian x 54 \\
\hline \multicolumn{4}{|c|}{ Beban biaya pekerja } \\
\hline \multicolumn{4}{|c|}{ A. Langsung } \\
\hline \multirow[t]{5}{*}{1} & \multicolumn{3}{|c|}{ Uang makan, lebur, dan transport } \\
\hline & -Uang makan & $\begin{array}{l}\text { Uang makan bulanan } \\
\text { Biaya makan bulanan }=\operatorname{Rp} 60.000,00 \times 25\end{array}$ & - \\
\hline & -Upah lembur & $\begin{array}{l}\text { Upah lembur bulanan = uang makan }+ \text { upah lembur } \\
\text { Upah lembur bulanan }=(\operatorname{Rp} 30.000,00 \times 33)+ \\
\text { upah lembur }\end{array}$ & 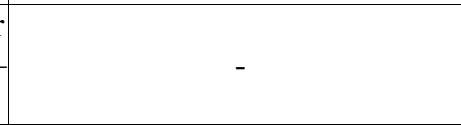 \\
\hline & -Uang transport & Kondisional & - \\
\hline & -Uang pulsa & Kondisional & - \\
\hline 2 & \multicolumn{3}{|l|}{ Bonus } \\
\hline & -THR & Minimal gaji pokok 1 bulan & - \\
\hline & -Bonus akhir tahun & Kondisional & - \\
\hline & -Bonus akhir proyek & Kondisional & - \\
\hline \multicolumn{4}{|c|}{ B. Tidak langsung } \\
\hline \multirow[t]{5}{*}{1} & \multicolumn{3}{|c|}{ Keselamatan dan kesehatan } \\
\hline & -Seragam kerja & Rp 250.000,00 per set & - \\
\hline & -APD & $\left.\begin{array}{l}\text { helm = Rp 150.000,00 } \\
\text { Rompi = Rp 50.000,00 } \\
\text { Safety shoes }=\operatorname{Rp~400.000,00~} \\
\text { Masker = Rp 5.000,00 × 4 x 12= Rp 240.000,00 }\end{array}\right\}$ dipakai 3 tahun & $\begin{array}{l}\text { Helm = Rp 20.000,00 } \\
\text { Rompi = Rp 25.000,00 } \\
\text { Sepatu boot = Rp 50.000,00 } \\
\text { Sarung tangan = Rp 2.500,00 }\end{array}$ \\
\hline & $\begin{array}{l}\text {-Iuran bpjs } \\
\text { ketenagakerjaan }\end{array}$ & $\begin{array}{c}\text { Iuran bulanan }=11,74 \% \text { x gaji pokok (menikah) } \\
\text { Atau } \\
\text { Iuran bulanan }=8,74 \% \text { x gaji pokok (lajang) }\end{array}$ & Lumpsum per proyek \\
\hline & -Premi asuransi & Kondisional & - \\
\hline 2 & Cuti & & \\
\hline & -Cuti tahunan & Cuti tahunan $=12 / 25 \mathrm{x}$ gaji pokok & - \\
\hline & -Cuti melahirkan & Cuti melahirkan $=3 \times$ gaji pokok & - \\
\hline & -Cuti sakit & Kondisional & - \\
\hline & $\begin{array}{l}\text {-Cuti keperluan } \\
\text { penting }\end{array}$ & Kondisional & - \\
\hline
\end{tabular}

Tabel 12. Komponen dan proporsi beban biaya pekerja konstruksi terhadap keseluruhan biaya upah

\begin{tabular}{|r|l|c|c|c|c|}
\hline No & \multicolumn{1}{|c|}{ Komponen } & \multicolumn{2}{c|}{ Pekerja tetap (non PM) } & \multicolumn{2}{c|}{ Pekerja lepas (tukang dan laden) } \\
\hline & & Besaran (Rp) & Persentase & Besaran (Rp) & Persentase \\
\hline I. & Upah/gaji & 3.510 .021 & $48,33 \%$ & 3.848 .838 & $99,79 \%$ \\
\hline II. & Beban biaya pekerja & 3.752 .868 & $51,67 \%$ & 8.125 & $0,21 \%$ \\
\hline A & Langsung & 2.348 .099 & $32,33 \%$ & & \\
\hline 1 & Uang makan dan lembur & & & & \\
\hline & -Makan & 817.218 & $11,25 \%$ & & \\
\hline & -Lembur & 1.220 .632 & $16,81 \%$ & & \\
\hline 2 & Bonus & & & & \\
\hline & -THR & 310.249 & $4,27 \%$ & & \\
\hline B & Tidak langsung & 1.404 .769 & $19,34 \%$ & & \\
\hline 1 & Keselamatan dan kesehatan & & & & \\
\hline & -Seragam kerja & 48.039 & $0,66 \%$ & & \\
\hline & -APD & 36.667 & $0,50 \%$ & & \\
\hline & -Iuran BPJS ketenagakerjaan & 365.079 & $5,03 \%$ & & \\
\hline 2 & Cuti & & & & \\
\hline & -Cuti tahunan & 140.401 & $1,93 \%$ & & \\
\hline & -Cuti melahirkan & 814.583 & $11,22 \%$ & & $100,00 \%$ \\
\hline Upah + beban biaya pekerja & 7.262 .889 & $100,00 \%$ & 3.856 .963 & \\
\hline
\end{tabular}


Tabel 13. Komponen dan proporsi beban biaya pekerja konstruksi (pm) terhadap keseluruhan biaya upah

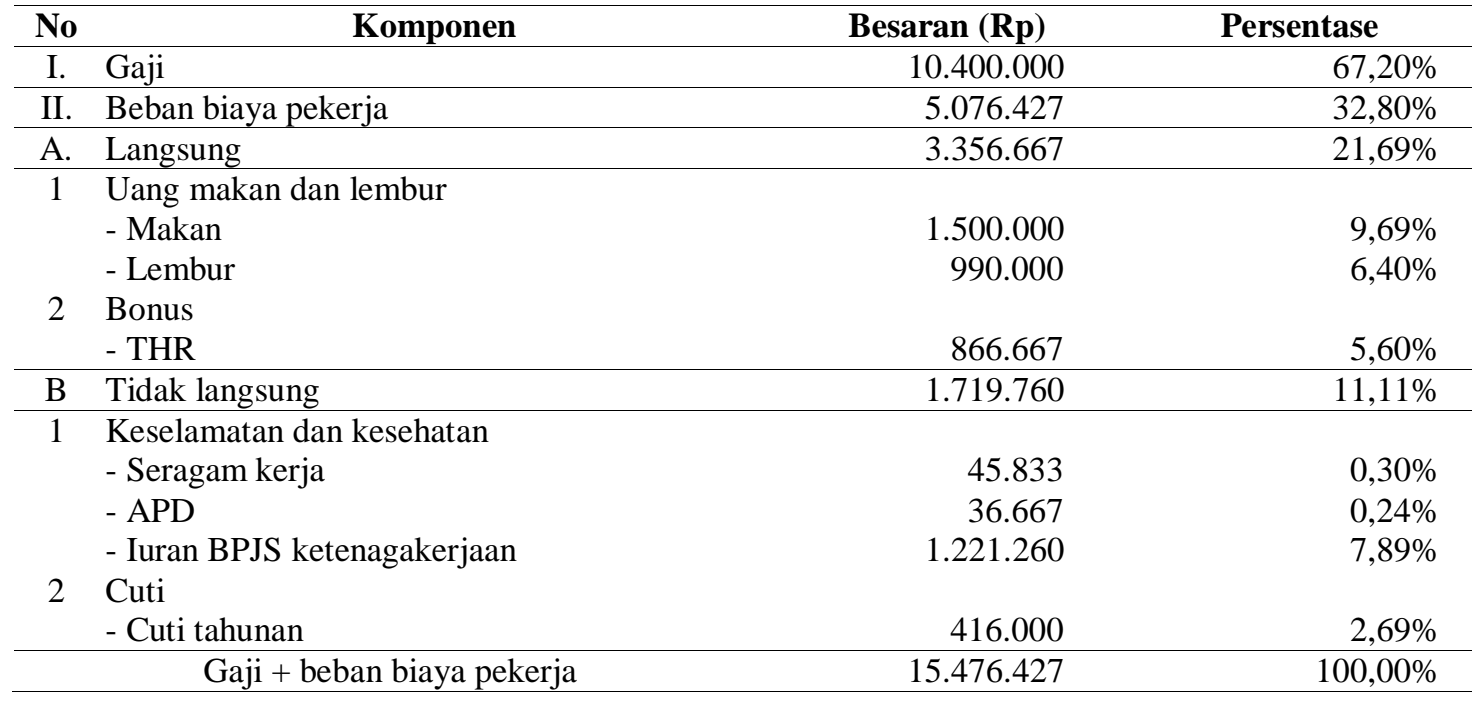

Tabel 14. Komponen dan proporsi beban biaya pekerja konstruksi (mandor dan wakil mandor) terhadap keseluruhan biaya upah

\begin{tabular}{clrrrr}
\hline \multirow{2}{*}{ No Komponen } & \multicolumn{1}{c}{ Mandor } & \multicolumn{3}{c}{ Wakil mandor } \\
\cline { 3 - 6 } & Besaran (Rp) & Persentase & Besaran (Rp) & Persentase \\
\hline I. & Upah & 5.334 .091 & $99,85 \%$ & 4.546 .458 & $99,82 \%$ \\
\hline Ii. & Beban biaya pekerja & 8.125 & $0,15 \%$ & 8.125 & $0,18 \%$ \\
\hline A & Tidak langsung & 8.125 & $0,15 \%$ & 8.125 & $0,18 \%$ \\
1 & Keselamatan dan kesehatan & & & & \\
& - APD & 8.125 & $0,15 \%$ & 8.125 & $0,18 \%$ \\
\hline \multicolumn{2}{l}{ Upah + beban biaya pekerja } & 5.342 .216 & $100,00 \%$ & 4.554 .583 & $100,00 \%$ \\
\hline
\end{tabular}

3. Identifikasi variabel yang berhubungan dengan upah dan beban biaya pekerja konstruksi

Sebelum menentukan metode yang akan digunakan untuk menganalisis variabel-variabel yang mempengaruhi tingkat upah dan beban biaya pekerja konstruksi, perlu dilakukan uji normalitas dan uji homogenitas data. Apabila data yang akan diuji terdistribusi normal dan homogen, maka dapat dilanjutkan dengan uji parametric (Independent-Samples $T$ test dan One Way ANOVA). Namun apabila salah satu persyaratan uji parametrik tersebut tidak terpenuhi, maka digunakan uji non-parametrik Kruskal-Wallis. Secara singkat, hasil uji analisis pengaruh variabelvariabel independen terhadap variabel dependen memberi indikasi pada Tabel 15.

Dari Tabel 15 diperoleh hasil bahwa secara umum variabel yang berhubungan dengan tingkat upah pekerja (baik pekerja tetap maupun pekerja lepas) adalah profil proyek (kota dan nilai kontrak) dan profil pekerja (jabatan, pengalaman kerja, dan status pernikahan). Sedangkan salah satu faktor yang sama sekali tidak berhubungan dengan tingkat upah dan beban biaya pekerja adalah tingkat pendidikan. Baik analisis serentak yang dilakukan terhadap kelompok pekerja tetap maupun analisis parsial per kelompok jabatan memberikan hasil bahwa tingkat pendidikan bukan merupakan variabel yang berhubungan dengan tingkat upah dan beban biaya pekerja. Analisis parsial per kelompok jabatan dilakukan pada jabatan yang di dalamnya terdapat variasi tingkat pendidikan responden, yaitu QC, SHE, SOM, GSP, QS, engineering, logistik, administrasi, drafter, dan supervisor. Variasi tingkat pendidikan untuk kelompok-kelompok pekerja tersebut adalah SMA, D3, S1, dan S2. Untuk lebih menguatkan hasil analisis tersebut dan untuk mengetahui penyebabnya, dilakukan wawancara terhadap pihak proyek. Adapun beberapa hal yang menyebabkan tidak adanya hubungan antara tingkat pendidikan dengan tingkat upah dan beban biaya pekerja yaitu:

- Untuk kelompok jabatan yang kebutuhan kompetensinya rendah, tetap dapat diisi oleh pekerja yang memiliki kompetensi lebih tinggi. Namun tingkat upah dan beban biaya pekerjanya mengikuti kebutuhan kompetensi akan jabatan tersebut. Sebagai contoh pada kelompok jabatan drafter. Kebutuhan tingkat pendidikan ini adalah SMA/SMK. 
Srie Heruyani Stevia Lukmanasari, Biemo W. Soemardi

Studi Upah dan Beban Biaya Pekerja Konstruksi di Indonesia (Studi Kasus: Pekerja Konstruksi Gedung di Pulau Jawa)

Tabel 15. Identifikasi variabel yang berhubungan dengan upah dan beban biaya pekerja konstruksi

\begin{tabular}{|c|c|c|c|}
\hline \multirow{2}{*}{ No } & \multirow{2}{*}{ Variabel independen } & \multicolumn{2}{|c|}{ Pengaruh terhadap } \\
\hline & & Upah/gaji & Beban biaya pekerja \\
\hline \multicolumn{4}{|c|}{ A. Pekerja tetap } \\
\hline \multicolumn{4}{|c|}{ profil perusahaan } \\
\hline 1 & Jenis perusahaan & & \\
\hline 2 & Kualifikasi perusahaan & $\sqrt{ }$ & \\
\hline 3 & Pengalaman perusahaan & & \\
\hline \multicolumn{4}{|c|}{ Profil proyek } \\
\hline 4 & Kota & $\sqrt{ }$ & $\sqrt{ }$ \\
\hline 5 & Kantor & & \\
\hline 6 & Nilai kontrak & $\sqrt{ }$ & $\sqrt{ }$ \\
\hline 7 & Durasi proyek & $\sqrt{ }$ & $\sqrt{ }$ \\
\hline \multicolumn{4}{|c|}{ Profil pekerja } \\
\hline 8 & Posisi (kantor-lapangan) & & $\sqrt{ }$ \\
\hline 9 & Jabatan & $\sqrt{ }$ & $\sqrt{ }$ \\
\hline 10 & Jenis kelamin & & \\
\hline 11 & Usia & $\sqrt{ }$ & \\
\hline 12 & Tingkat pendidikan & & \\
\hline 13 & Pengalaman kerja & $\sqrt{ }$ & $\sqrt{ }$ \\
\hline 14 & Sertifikasi & $\sqrt{ }$ & $\sqrt{ }$ \\
\hline 15 & Status pernikahan & $\sqrt{ }$ & $\sqrt{ }$ \\
\hline \multicolumn{4}{|c|}{ B. Pekerja lepas (tukang-laden) } \\
\hline \multicolumn{4}{|c|}{ Profil perusahaan } \\
\hline 1 & Jenis perusahaan & & \\
\hline 2 & Kualifikasi perusahaan & & \\
\hline 3 & Pengalaman perusahaan & & \\
\hline \multicolumn{4}{|c|}{ Profil proyek } \\
\hline 4 & Kota & $\sqrt{ }$ & \\
\hline 5 & Kantor & $\sqrt{ }$ & \\
\hline 6 & Nilai kontrak & $\sqrt{ }$ & \\
\hline 7 & Durasi proyek & & \\
\hline \multicolumn{4}{|c|}{ Profil pekerja } \\
\hline 8 & Jabatan & $\sqrt{ }$ & \\
\hline 9 & Jenis kelamin & & \\
\hline 10 & Usia & & \\
\hline 11 & Tingkat pendidikan & & \\
\hline 12 & Pengalaman kerja & $\sqrt{ }$ & \\
\hline 13 & Sertifikasi & & \\
\hline 14 & Status pernikahan & $\sqrt{ }$ & \\
\hline \multicolumn{4}{|c|}{ C. Pekerja lepas (mandor-wakil mandor) } \\
\hline \multicolumn{4}{|c|}{ Profil perusahaan } \\
\hline 1 & Jenis perusahaan & & \\
\hline 2 & Kualifikasi perusahaan & & \\
\hline 3 & Pengalaman perusahaan & & \\
\hline \multicolumn{4}{|c|}{ Profil perusahaan } \\
\hline 4 & Kota & & \\
\hline 5 & Kantor & & \\
\hline 6 & Nilai kontrak & & \\
\hline 7 & Durasi proyek & & \\
\hline \multicolumn{4}{|c|}{ Profil pekerja } \\
\hline 8 & Jabatan & & \\
\hline 9 & Jenis kelamin & & \\
\hline 10 & Usia & & \\
\hline 11 & Tingkat pendidikan & & \\
\hline 12 & Pengalaman kerja & $\sqrt{ }$ & \\
\hline 13 & Sertifikasi & & \\
\hline 14 & Status pernikahan & & \\
\hline
\end{tabular}


Pada kenyataannya berdasarkan hasil survei, ada pula pekerja dengan tingkat pendidikan D3 dan S1 yang juga mengisi jabatan ini. Namun tingkat upah dan beban biaya pekerjanya mengikuti standar untuk jabatan ini, yang notabene kebutuhan kompetensinya adalah untuk tingkat pendidikan SMA/SMK.

- Untuk mencapai level suatu jabatan, dapat ditempuh dengan dua cara, yaitu melalui tingkat pendidikan atau pengalaman kerja. Sebagai contoh, terdapat responden dengan tingkat pendidikan mulai dari SMA/SMK hingga S1 pada kelompok jabatan SOM. Responden dengan tingkat pendidikan $\mathrm{S} 1$ memiliki pengalaman kerja yang lebih rendah dibandingkan dengan yang tingkat pendidikannya SMA/SMK.

- Penentuan standar tingkat upah dan beban biaya pekerja tidak sama antara satu perusahaan dengan perusahaan yang lain, tergantung kebijakan masing-masing. Sebagai contoh, berdasarkan hasil survei diperoleh responden dengan profil (jenis kelamin, usia, tingkat pendidikan, pengalaman kerja, sertifikasi, dan status pernikahan) yang sama namun tingkat upah dan beban biaya pekerjanya berbeda.

Sedikit berbeda dengan kelompok pekerja tetap dan kelompok tukang-laden, pada kelompok mandor-wakil mandor variabel jabatan tidak berhubungan dengan tingkat upah dan beban biaya pekerja.

Salah satu penyebabnya adalah wakil mandor hanyalah asisten/perwakilan dari mandor untuk suatu proyek tertentu karena mandor tersebut tidak hanya bertanggung jawab pada satu proyek saja. Sehingga tingkat upah dan beban biaya pekerja kelompok wakil mandor tidak jauh berbeda dari mandornya.

Di samping itu, salah satu persamaan pekerja tetap dan pekerja lepas adalah variabel kota berhubungan dengan tingkat upah dan beban biayanya. Analisis terhadap variabel kota ini dilakukan dengan mempertimbangkan faktor UMR sebagai kelompok data ordinal, di mana kota diurutkan dari nilai UMR yang terkecil.

Hasil analisis menggunakan uji Kruskal-Wallis memberikan indikasi bahwa terdapat perbedaan yang signifikan antara rerata upah dan beban biaya pekerja pada kelima kota penelitian. Sehingga, dapat disimpulkan bahwa UMR turut memiliki hubungan dengan tingkat upah dan beban biaya pekerja konstruksi.

\section{Kesimpulan}

Dari analisis data diatas dapat disimpulkan bahwa:

1. Baik pekerja tetap maupun pekerja lepas konstruksi memiliki beban biaya pekerja di luar upah/gajinya. Pada pekerja tetap, proporsi beban biaya pekerja terhadap keseluruhan biaya upahnya berkisar antara 33-52\%, yang terdiri dari $22-32 \%$ beban biaya yang dibayarkan secara langsung dan 11-19\% beban biaya yang dibayarkan secara tidak langsung. Sedangkan pada pekerja lepas, proporsi beban biaya pekerja terhadap keseluruhan biaya upah hanya sekitar $0,2 \%$, yang terdiri dari beban biaya yang dibayarkan secara tidak langsung. Namun demikian, baik untuk pekerjaa tetap maupun pekerja lepas masih ada beban biaya pekerja yang bersifat kondisional dan lumpsump per proyek.

2. Secara umum, tingkat upah/gaji pekerja tetap dan pekerja lepas tergantung dari profil perusahaan, profil proyek dan profil pekerja. Sedangkan untuk tingkat beban biaya, pada pekerja tetap tergantung dari profil proyek dan profil pekerja serta pada pekerja lepas tidak berhubungan dengan faktor apapun karena hanya terdiri dari APD yang merupakan perangkat wajib proyek.

\section{Saran}

Dari analisis data diatas maka ada beberapa saran sebagai berikut:

1. Berdasarkan hasil penelitian ini, dapat dilakukan studi lebih lanjut untuk mengetahui pengaruh (causal relationship) antara variabel-variabel yang diteliti. Sangat disarankan untuk menggunakan lebih banyak jumlah responden.

2. Perlu dilakukan studi lanjutan untuk mengetahui hubungan antara keahlian/ keterampilan pekerja dengan upah dan beban biayanya.

3. Hasil dari penelitian ini dapat digunakan oleh perusahaan kontraktor dalam mengelola sumber daya manusianya (pekerja) dengan lebih baik lagi guna mencapai produktivitas yang lebih tinggi.

\section{Daftar Pustaka}

Badan Pusat Statistik Nasional, 2014. Benchmark Statistik Konstruksi 1990-2012. From http://www.bps.go.id/hasil_publikasi/bench_stat_k onstruksi_1990_2012/index3.php?pub=Benchmark 
\%20Statistik\%20Konstruksi\%202008-2012, $\quad 10$ Juni 2014

Hedley, George, 2007. Is Your Bid Only an Estimate?. Indianapolis: Associated Construction Publications, LLC.

Huston, Jim, 2004. How to Calculate Labor Burden, J. R. Huston, Inc.

Peraturan LPJK No. 04 Tahun 2011 tentang Tata Cara Registrasi Ulang, Perpanjangan Masa Berlaku, dan Permohonan Baru Sertifikat Tenaga Kerja Ahli Konstruksi.

Peraturan LPJK No. 05 Tahun 2011 tentang Tata Cara Registrasi Ulang, Perpanjangan Masa Berlaku, dan Permohonan Baru Sertifikat Tenaga Kerja Terampil Konstruksi.

Peraturan Menteri Tenaga Kerja dan Transmigrasi Republik Indonesia No. 5 Tahun 2012 tentang Sistem Standarisasi Kompetensi Kerja Nasional.

Peraturan Pemerintah Republik Indonesia No. 14 Tahun 1993 tentang Penyelenggaraan Program Jamsostek.

Peraturan Pemerintah Republik Indonesia No. 31 Tahun 2006 tentang Sistem Pelatihan Kerja Nasional.

Peraturan Pemerintah Republik Indonesia No. 84 Tahun 2013 tentang Perubahan Kesembilan atas PP No. 14 Tahun 1993 tentang Penyelenggaraan Program Jamsostek.
Rabinaw, Steven K., 2006. Prevailing Wage is All The Rage, Thomson Professional and Regulatory Services Inc, Boston

Soekiman, Anton, dkk., 2011. Study on Factors Affecting Project Level Productivity in Indonesia, Annals of Faculty Engineering HunedoaraInternational Journal of Engineering.

Soemardi, B. W., dkk., 2010. Assessing the Role and Competence of Mandor in Indonesian Construction Industry, Second International Conference on Construction in Developing Countries (ICCIDC-II). 29 April 2014.

Soemardi, B.W., Rani Gayatri Kusumawardani. 2010. Studi Praktek Estimasi Biaya Tidak Langsung pada Proyek Konstruksi, Konferensi Nasional Teknik Sipil 4 (KoNTekS 4).

Soemardi, B. W., Teguh L., Santoso, 2005. Kajian Penerapan Outsourcing pada Perusahaan Kontraktor dan Konsultan, Repositori Teknik Sipil Institut Teknologi Bandung, Bandung.

Undang-undang Republik Indonesia No. 13 Tahun 2003 tentang Ketenagakerjaan.

Wuryanti, Wahyu, 2010. Standarisasi Pedoman Pengukuran Produktivitas Tenaga Kerja untuk Pekerjaan Konstruksi Bangunan Gedung, Prosiding PPI Standarisasi 2010.

Wikipedia (2014). Employee Benefit. From http://en.wikipedia.org/wiki/Employee_benefit, 4 Mei 2014. 